NOTE

\title{
Taura syndrome virus from Penaeus vannamei shrimp cultured in Korea
}

\author{
Jeong Wan Do ${ }^{1}$, Seung Ju Cha ${ }^{1,3}$, Nam Sil Lee ${ }^{1}$, Yi Cheong Kim ${ }^{1}$, Jin Woo Kim ${ }^{1}$, \\ Jae Dong Kim², Jeong Woo Park ${ }^{3, *}$
}

${ }^{1}$ Pathology Division, National Fisheries Research \& Development Institute, Kijang, Busan 619-902, ROK

${ }^{2}$ Daesan Regional Maritime Affairs and Fisheries Office, Seosan 356-871, ROK

${ }^{3}$ Department of Biological Sciences, University of Ulsan, Ulsan 680-749, ROK

\begin{abstract}
Mass mortality occurred among Penaeus vannamei shrimp cultured in Korea in 2004. In an earlier study, we reported white spot syndrome virus (WSSV) as a causative agent of mass mortality of P. monodon shrimp in Korea (Moon et al. 2003; Dis Aquat Org 53:11-13). However, in the present study, we detected Taura syndrome virus (TSV) from the moribund 2004 P. vannamei shrimp by reverse transcription polymerase chain reaction (RT-PCR). In addition, during our regular screening for the TSV in stocks of $P$. vannamei imported from Hawaii, USA, we also detected TSV by RTPCR. The nucleotide sequences of the partial capsid protein VP1 of 2 Korean isolates were $99 \%$ identical to each other and 96 to $99 \%$ identical to those of TSVs isolated from the Americas, Taiwan, and Thailand. Phylogenetic analysis revealed that the 2 Korean isolates were closely related to TSV types from Thailand. This is the first report on the detection of TSV during an epizootic among cultured $P$. vannamei in Korea, and our results suggests the possibility that TSV has been introduced via the imported stock of $P$. vannamei.
\end{abstract}

KEY WORDS: TSV $\cdot$ Penaeus vannamei $\cdot$ RT-PCR $\cdot$ VP1

Taura syndrome (TS) virus (TSV) was first described in farmed shrimp near the Taura river, Ecuador, in 1992 (Jimenez 1992). TS, caused by TSV, has resulted in serious disease epizootics among cultured penaeid shrimp in the Western Hemisphere (Brock et al. 1995, Hasson et al. 1995). Penaeus vannamei, P. schmitti and $P$. setiferus are the most susceptible species, whereas $P$. monodon, $P$. japonicus, $P$. duorarum, P. chinensis and $P$. aztecus are considered TSV tolerant (Brock et al. 1997, Overstreet et al. 1997). Due to the extensive farming and international movement of $P$. vannamei, TSV has spread via infected stocks throughout the Americas (Hasson et al. 1999) and has recently been introduced into Taiwan and Thailand (Tu et al. 1999, Nielsen et al. 2005).

TSV is a non-enveloped, icosahedra, 31 to $32 \mathrm{~nm}$ in diameter and contains a single-stranded RNA mole- cule and, based on its physical and chemical properties, was determined to be a member of the family Picornaviridae (Bonami et al. 1997). However, nucleotide sequence data suggest that TSV is more closely related to the Cricket paralysis viruses and classified in the family Dicistroviridae, genus Cripavirus (Mari et al. 2002, Mayo 2002). The genome of TSV has been sequenced completely and consists of a linear, positive-sense, single-stranded RNA of 10205 nucleotides (nt) (Mari et al. 2002) and includes 2 large open reading frames (ORFs) (ORF1 and ORF2). ORF 1 contains the sequence motifs for nonstructural proteins, such as helicase, protease and RNA-dependent RNA polymerase. ORF 2 contains the sequences for TSV structural proteins, including the 3 major capsid proteins, VP1, VP2 and VP3 $(55,40$, and $24 \mathrm{kDa}$, respectively) (Bonami et al. 1997, Mari et al. 1998, 2002). 
Until recently, white spot syndrome virus (WSSV) has been reported to be the major economically significant virus infecting cultured penaeid shrimp in Korea (Park et al. 1998, Moon et al. 2003, Seok et al. 2004). In 2004, mass mortality occurred among cultured Penaeus vannamei shrimp along the western coast of Korea and we confirmed the presence of TSV instead of WSSV in the tissues of moribund shrimp by RT-PCR. In addition, we detected TSVs from stock of $P$. vannamei imported from Hawaii, USA. In order to identify the characteristics of these Korean isolates of TSV, the partial VP1 genes were cloned and their sequences were compared with each other and with the available pool of TSV gene sequences in the GenBank/EMBL databases. Based on phylogenetic analysis, we confirmed the occurrence of TSVs in Korea which are closely related to TSV types from Thailand. This is the first report on the detection of TSV from diseased penaeid shrimp during epizootics in Korea.

The virus samples used in this study were obtained from moribund Penaeus vannamei shrimps grown in the Cheonsu bay area on the western coast of Korea during epizootics in 2004 (Fig. 1). TSV-infected stocks of $P$. vannamei imported from Hawaii with no visible signs of TS were also used in this study. Infected tissue was homogenized in TN buffer $(20 \mathrm{mM}$ Tris- $\mathrm{HCl}$ and $400 \mathrm{mM} \mathrm{NaCl}, \mathrm{pH} 7.4$ ). After centrifugation at $1700 \times g$ for $10 \mathrm{~min}$, the supernatant was treated with Proteinase $\mathrm{K}\left(0.2 \mathrm{mg} \mathrm{ml}^{-1}\right)$ and sarcosyl $(1 \%)$ at $45^{\circ} \mathrm{C}$ for $3 \mathrm{~h}$, followed by phenol/chloroform extraction and ethyl alcohol precipitation. The genomic DNA in the pellet was dissolved in TE $(10 \mathrm{mM}$ Tris- $\mathrm{HCl}$ and $1 \mathrm{mM}$ EDTA, pH 7.5) and used as a template for PCR.

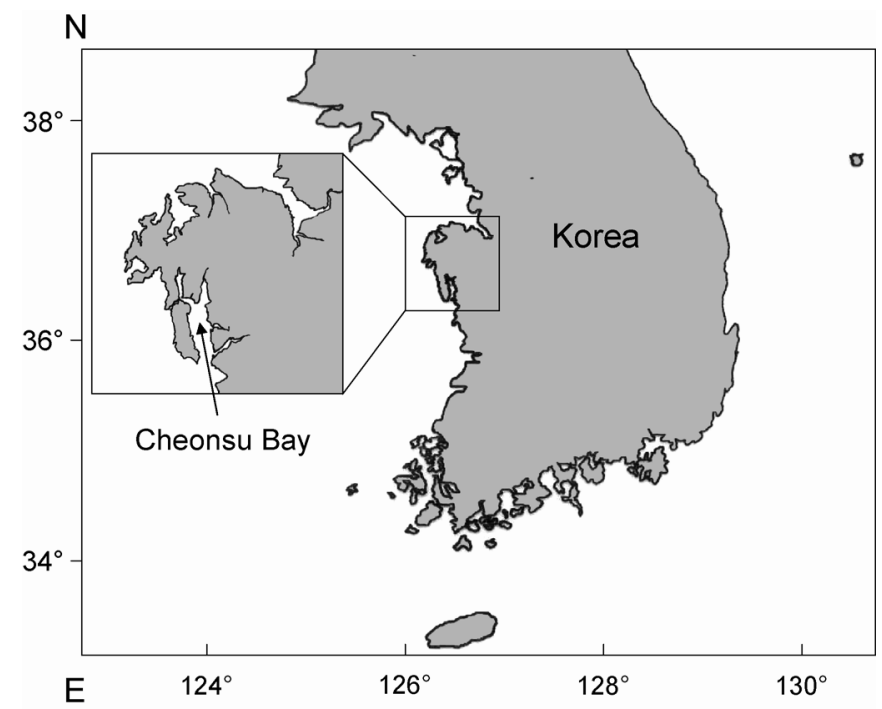

Fig. 1. Location of shrimp farm where epizootics occurred and Taura syndrome virus (TSV) was isolated (arrow)
In addition total RNA was isolated from the tails of moribund shrimp using an RNA extraction kit (High Pure RNA Tissue Kit, Roche) and $5 \mu \mathrm{g}$ of DNase Itreated total RNA was reverse transcribed using random priming and Superscript II reverse transcriptase (Invitrogen), according to the manufacturer's instructions.

PCR was performed to amplify partial genes of WSSV VP28 and TSV VP1. Primers for PCR were designed from nucleotide sequences in the GenBank/EMBL database of WSSV VP28 (AF295123) and TSV VP1 (AY355311). The PCR primers were as follows. WSSV VP upstream: 5'-ATCATGGCTGCTTCAGAGAC-3'; WSSV VP downstream: 5'-GGCTGGAGAGGACAAGACAT-3'; TSV VP upstream: 5'-TCCC AAT AAG TGG ATG CGA GT-3'; TSV VP downstream: 5'-CGT CTC CTC GGA AAT ACC AA-3'. The templates were genomic DNA from the infected tissues or cDNA from the tails of Penaeus vannamei. The gene amplification reaction conditions were as follows: 1 cycle of $94^{\circ} \mathrm{C}$ for $5 \mathrm{~min} ; 30$ cycles of $94^{\circ} \mathrm{C}$ for $30 \mathrm{~s}, 55^{\circ} \mathrm{C}$ for $45 \mathrm{~s}$, and $72^{\circ} \mathrm{C}$ for $45 \mathrm{~s}$; and 1 cycle of $72^{\circ} \mathrm{C}$ for $5 \mathrm{~min}$. The amplified PCR products were cloned into pGEM-T vector (Promega), and sequencing was performed at the Immunomodulation Research Center, Korea, on an automatic DNA sequencer (Applied Biosystems) according to the dye terminator procedure with forward and reverse primers and overlapping primers designed from the sequencing results. The DNA and the deduced amino acid sequences were compared with the GenBank/EMBL databases using the basic local aligment search tool (BLAST).

The nucleotide sequences were compared with the GenBank/EMBL databases using BLAST. Sequences were aligned using CLUSTAL W (Thompson et al. 1994) and then the phylogenetic tree was constructed with TreeView (Page 1996). The phylogenetic relationships among species were determined using the neighbor-joining (NJ) method (Saitou \& Nei 1987) and the reliability of the NJ tree was inferred using the Felsentein (Felsenstein 1985) bootstrap method with 1000 replicates.

The nucleotide sequence data reported in this paper were deposited to the GenBank (GenBank accession numbers: KOR-CsPv04TSV, DQ099912; KORImPv05TSV, DQ099913).

During the epizootics in 2004, gross mortality occurred among Penaeus vannamei shrimp cultured on the Korean western coast. Previously, we reported WSSV as a causative agent of mass mortality among cultured shrimp in Korea (Moon et al. 2003). Thus, at first, we tried to detect WSSV by PCR amplification of the VP28 gene. However, even though we tried more than 10 samples, we could not obtain any PCR product. The moribund shrimps were pale and reddish in color 
and were lethargic and soft-shelled at the time of sampling. These results suggested that the causative agent could be TSV. In order to confirm this, the partial gene of VP1 of TSV was amplified by RT-PCR and we were able to obtain the PCR product. A PCR product of $571 \mathrm{bp}$ was cloned into pGEM-T vector and sequenced. BLAST analysis of the nucleotide sequences revealed 97 to $99 \%$ identity to those of TSV VP1 genes in the GenBank/EMBL databases isolated from Thailand (ThOct03LvTSV, AY912503), Taiwan (Tw2KMeTSV, AY355310) and the Americas (MX99TSV, AF510516).

We named the Korean TSV isolate KOR-CsPv04TSV and, in order to determine the relationship between KOR-CsPv04TSV and previously reported TSVs, we compared the partial nucleotide sequences of the VP1 of KOR-CsPv04TSV to those of 16 other TSVs available from GenBank. In the VP1 tree, coinciding with the report of Nielsen et al. (2005), the TSVs used in the multiple alignments were divided into 3 groups (Fig. 2). Group 1 contained TSVs isolated from Thailand such as ThJul04LvTSV, ThOct03LvTSV, ThMay04PmPLTSV, ThMar04Pm2TSV, and ThMar 04LvTSV. Group 2 contained TSVs from the Americas and Europe such as TSV-Bl, HI94TSV, TSV-Fr-1, SIN98TSV, TSV-Mx-1, MX99TSV, and SON2KTSV. Group 3 contained TSVs from Taiwan such as Tw2KMeTSV, Tw2KPmTSV, TSV-Tw-1, and Tw02 PvTSV. The Korean isolate, KOR-CsPv04TSV, is clustered within Group 1 and this finding indicates that the members of Group 1 may be responsible for the epizootics of shrimp in Korea.

Prior to the present study, Korea was considered to be free of TSV. However, our results suggest that TSV has now been introduced into Korea. It is not clear when and how this occurred. It is highly possible that TSV was introduced into Korea via imported stocks of Penaeus vannamei. Within the last few years, bloodstock $P$. vannamei has been imported from various countries. In order to prevent the introduction of TSV, the National Fisheries Research \& Development Institute of Korea has screened every imported stock of shrimp for TSV by RT-PCR. Recently, during our regular screening for TSV of stocks of $P$. vannamei imported from Hawaii, we detected the presence of TSV by RT-PCR. We named it KOR-ImPv05TSV and compared the nucleotide sequences of the VP1 of KOR-ImPv05TSV to those of another Korean TSV isolate, KOR-CsPv04TSV, and other foreign TSV isolates. Phylogenetic analysis revealed that KOR-ImPv05TSV clustered into Group 1 including the KOR-CsPv04TSV. This finding strongly suggests that TSV has been introduced into Korea via imported stocks of shrimp.

Even though TSV has been introduced into Korea, it does not seem to be widespread in cultured Korean shrimp. However, it is likely that TSV will spread to

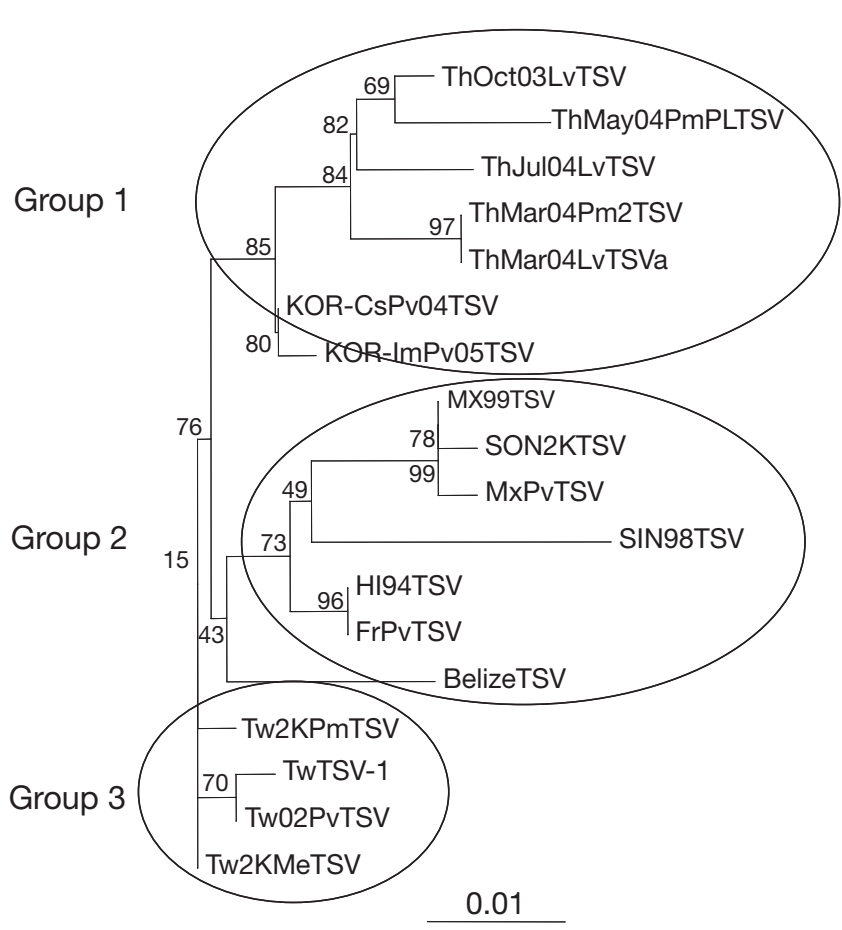

Fig. 2. Phylogenetic analysis of TSV VP1. Partial nucleotide sequences of the VP1 of Korean isolate of TSV were compared with those from 16 TSVs. GenBank accession numbers for nucleotide sequences are as follows: Tw2KMeTSV (Metapenaeus ensis, Taiwan), AY355310; Tw02PvTSV (P. vannamei, Taiwan), AY355311; Tw2KPmTSV (P. monodon, Taiwan), AY355309; ThMar04Pm2TSV (P. monodon, Thailand), AY912506; ThMar04LvTSV ( $P$. vannamei, Thailand), AY912504; ThJul04LvTSV ( $P$. vannamei, Thailand), AY912508; ThOct03LvTSV ( $P$. vannamei, Thailand), AY912503; ThMay04PmPLTSV ( $P$. monodon, Thailand), AY912507; HI94TSV ( $P$. vannamei, Hawaii), AF510518; SIN98TSV ( $P$. vannamei, Mexico), AF510515; MX99TSV $(P$. vannamei, Mexico), AF510516; SON2KTSV ( $P$. vannamei, Mexico), AF510517; TwTSV-1 (Tawain), AF406789; KORCsPv04TSV, DQ099912; KOR-ImPv05TSV, DQ099913; BelizeTSV (Belize), AY590471; FrPvTSV ( $P$. vannamei, France), AF277675; MxPvTSV (P. vannamei, Mexico), AF277378. The multiple alignments of the TSV VP1 nucleotide sequence were performed using the CLUSTAL $\mathrm{W}$, and phylogenetic analysis was constructed using TreeView. The bootstrap values are indicated on the tree

shrimp farms over a wide area through the transfer of shrimp among shrimp farms. In addition, cross-species transmission of TSV from Penaeus vannamei to other shrimp species such as $P$. monodon may occur because $P$. monodon as well as $P$. vannamei are intensively cultured in the Cheonsu bay area. P. monodon was first considered to be TSV tolerant (Brock 1997, Overstreet et al. 1997). However, TSV has beendetected in $P$. monodon in more recent studies (Chang et al. 2004, Nielsen et al. 2005), and the existence of genetic variants has been reported by Robles-Sikisaka et al. (2002). Furthermore, a variant of TSV was found to 
replicate freely in $P$. monodon (Chang et al. 2004). Thus, preventing the spread of TSV to other shrimp farms, and especially to other shrimp species, such as $P$. monodon, is essential

Here, we have isolated TSV from diseased Penaeus vannamei shrimp during an epizootic in Korea. A phylogenetic analysis of the Korean TSV isolate, based on the partial nucleotide sequences of the VP1, revealed that the Korean isolates are closely related to TSV types from Thailand. Recently, in Korea, we have observed a rapid spread of WSSV among $P$. monodon, and $P$. monodon farmers have consequently suffered economic losses. The spread of TSV throughout shrimp farms in Korea would have a serious negative impact on the shrimp industry. Thus, there is an urgent need to prevent a further spread of TSV to other shrimp species and to other geographic regions.

\section{LITERATURE CITED}

Bonami JR, Hasson KW, Mari J, Poulos BT, Lightner DV (1997) Taura syndrome of marine shrimp: characterization of the viral agent. J Gen Virol 78:313-319

Brock JA, Gose RB, Lightner DV, Hasson KW (1995) An overview on Taura syndrome, an important disease of farmed Penaeus vannamei. In: Browdy CL, Hopkins JS (eds) Swimming through troubled water. Proceedings of the Special Session on Shrimp Farming, Aquaculture 1995. World Aquaculture Society, Baton Rouge, LA, p 84-94

Brock JA, Gose RB, Lightner DV, Hasson KW (1997) Recent developments and an overview of Taura syndrome of farmed shrimp in the Americas. In: Flegel TW, MacRae IH (eds) Diseases in Asian aquaculture III. Asian Fisheries Society, Manila, p 275-283

Chang YS, Peng SE, Yu HT, Liu FC, Wang CH, Lo CF, Kou GH (2004) Genetic and phenotypic variations of isolates of shrimp Taura syndrome virus found in Penaeus monodon and Metapenaeus ensis in Taiwan. J Gen Virol 85:2963-2968

Felsenstein J (1985) Confidence limits on phylogenies: an approach using bootstrap. Evolution 39:783-791

Hasson KW, Lightner DV, Poulos BT, Redman RM, White BL, Brock JA, Bonami JR (1995) Taura syndrome in Penaeus vannamei: demonstration of a viral etiology. Dis Aquat Org 23:115-126

Hasson KW, Lightner DV, Mari J, Bonami JR and 5 others (1999) The geographic distribution of Taura syndrome virus (TSV) in the Americas: determination by histopath-

Editorial responsibility: Jo-Ann Leong,

Kaneohe, Hawaii, USA ology and in situ hybridization using TSV-specific cDNA probes. Aquaculture 171:13-26

Jimenez, R (1992) Síndrome de Taura (resumen). Rev Acuacult Ecuador 1:1-16 (in Spanish)

Mari J, Bonami JR, Lightner DV (1998) Taura syndrome of penaeid shrimp: cloning of viral genome fragments and development of specific gene probes. Dis Aquat Org 33:11-17

Mari J, Poulos BT, Lightner DV, Bonami JR (2002) Shrimp Taura syndrome virus: genomic characterization and similarity with members of the genus Cricket paralysis-like viruses. J Gen Virol 83:915-926

Mayo MA (2002) A summary of taxonomic changes recently approved by ICTV. Arch Virol 147:1655-1657

Moon CH, Do JW, Cha SJ, Yoon WJ and 7 others (2003) Highly conserved sequences of three major virion proteins of a Korean isolate of white spot syndrome virus (WSSV). Dis Aquat Org 53:11-13

Nielsen L, Sang-oum W, Cheevadhanarak S, Flegel W (2005) Taura syndrome virus (TSV) in Thailand and its relationship to TSV in China and the Americas. Dis Aquat Org 63:101-106

Overstreet RM, Lightner DV, Hasson KW, Mcvllwain S, Lotz JM (1997) Susceptibility to Taura syndrome virus of some penaeid shrimp species native to the Gulf of Mexico and the Southeastern United States. J Invertebr Pathol 69:165-176

Page RDM (1996) TreeView: an application to display phylogenetic trees on personal computers. Comput Appl Biosci 12:357-358

Park JH, Lee YS, Lee S, Lee Y (1998) An infectious viral disease of penaeid shrimp newly found in Korea. Dis Aquat Org 34:71-75

Robles-Sikisaka R, Hasson KW, Garcia DK, Brovont KE, Cleveland KD, Klimpel KR, Dhar AK (2002) Genetic variation and immunohistochemical differences among geographic isolates of Taura syndrome virus of penaeid shrimp. J Gen Virol 83:3123-3130

Saitou N, Nei M (1987) The neighbor-joining method: a new method for reconstructing phylogenetic trees. Mol Biol Evol 4:406-425

Seok SH, Park JH, Cho SA, Baek MW, Lee HY, Kim DJ, Park JH (2004) Cloning and sequencing of envelope proteins (VP19, VP28) and nucleocapsid proteins (VP15, VP35) of a white spot syndrome virus isolate from Korean shrimp. Dis Aquat Org 60:85-88

Thompson JD, Higgins DG, Gibson TJ (1994) CLUSTAL W: improving the sensitivity of progressive multiple sequence alignment through sequence weighting, position-specific gap penalties and weight matrix choice. Nucleic Acids Res 22:4673-4680

Tu C, Huang HT, Chuang SH, Hsu JP and 5 others (1999) Taura syndrome in Pacific white shrimp Penaeus vannamei cultured in Taiwan. Dis Aquat Org 38:159-161

Submitted: June 23, 2005; Accepted: December 7, 2005

Proofs received from author(s): April 12, 2006 